\title{
Kinetics of Gas Reactions and Environmental Degradation in NGNP Helium
}

Richard N. Wright

June 2006

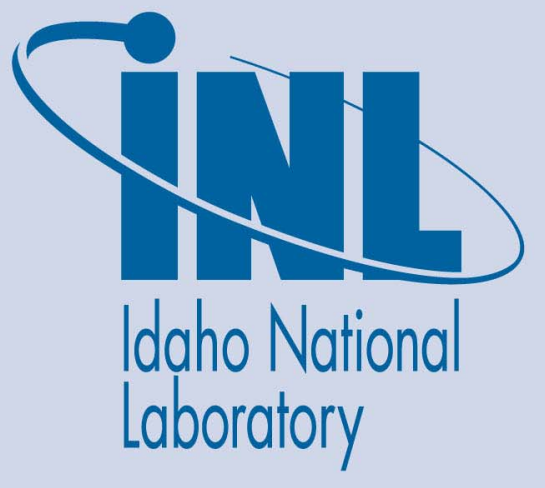

The INL is a U.S. Department of Energy National Laboratory operated by Battelle Energy Alliance 


\title{
Kinetics of Gas Reactions and Environmental Degradation in NGNP Helium
}

\author{
Richard N. Wright
}

June 2006

\begin{abstract}
Idaho National Laboratory
Idaho Falls, Idaho 83415
\end{abstract}

Prepared for the

U.S. Department of Energy

Office of Nuclear Energy

Under DOE Idaho Operations Office

Contract DE-AC07-05ID14517 
This page intentionally left blank. 


\section{SIGNATORS}

George O. Hayner

Date

NGNP Materials Program Manager

Idaho National Laboratory

Kevan Weaver

Date

NGNP Systems Integration Manager

Idaho National Laboratory 
This page intentionally left blank. 


\section{EXECUTIVE SUMMARY}

A number of very high temperature helium-cooled reactors have been built and operated for extended periods. The helium coolant in the primary circuit has been found to contain low levels of impurities after steady-state operation that can lead to an environmental degradation of the high temperature alloys used for internals and heat exchangers. Depending on the impurity concentration and the temperature, high temperature alloys can undergo oxidation, carburization, or decarburization. The concentration of $\mathrm{H}_{2} \mathrm{O}$ and $\mathrm{CC}$ are of particular interest because they essentially control the oxygen partial pressure and carbon activity, respectively. The optimum coolant chemistry for long-term stability of high temperature alloys is slightly oxidizing and results in formation of a tenacious and protective $\mathrm{Cr}_{2} \mathrm{O}_{3}$ scale.

The most critical metallic component of the Next Generation Nuclear Plant (NGNP) is the heat exchanger. Inconel 617 is the primary candidate alloy for this application because of its superior creep resistance. The mechanisms of environmental interaction between this alloy and prototype Very High Temperature Reactor (VHTR) helium chemistries have been extensively studied. A modified type of Ellingham diagram that maps the ranges of carbon activity and oxygen partial pressure that result in each of the degradation mechanisms has been developed. In addition, at temperatures above about $950^{\circ} \mathrm{C}$, additional degradation mechanisms arise that effectively determine the maximum temperature for sustained service. While the mechanisms of degradation are relatively well-known, the kinetics of the reactions for reactor conditions of high helium pressure and velocity are not well characterized.

The NGNP materials program has extended previous studies on environmental effects of prototype impure helium on Inconel 617 by increasing temperatures and using test coupons that incorporate fusion welds in controlled chemistry test loops. In addition, parallel studies have been initiated with a less wellcharacterized alloy, Haynes 230. The goal of this work is to determine the range of gas chemistries that give rise to stable oxide formation for these alloys at temperatures up to potentially $1000^{\circ} \mathrm{C}$. Through an International Nuclear Research Initiative agreement with the French Generation IV materials program, the upper temperature limit determined by the so-called "microclimate reaction," or $\mathrm{Cr}_{2} \mathrm{O}_{3}$ volatility, will be determined. 
This page intentionally left blank. 


\section{CONTENTS}

SIGNATORS

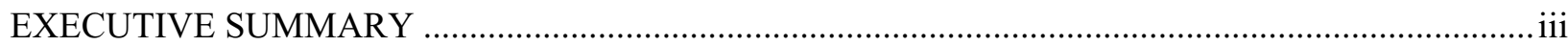

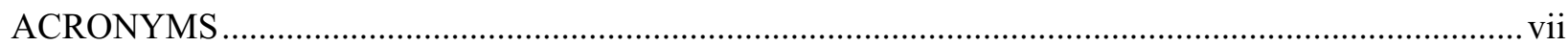

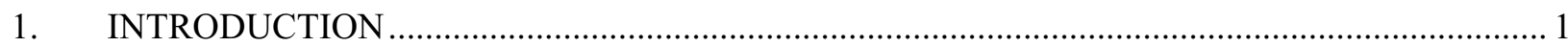

2. IMPURITIES IN HELIUM-COOLED HIGH TEMPERATURE GAS-COOLED

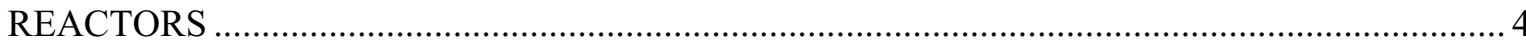

3. ENVIRONMENTAL INTERACTIONS BETWEEN VHTR HELIUM AND HIGH

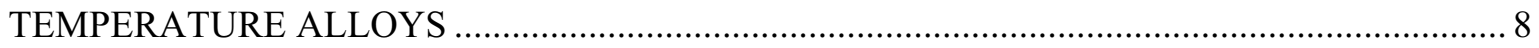

4. CURRENT TESTING PROGRAMS FOR VHTR ENVIRONMENTAL INTERACTIONS......... 13

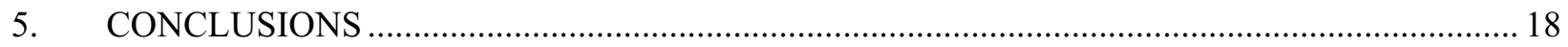

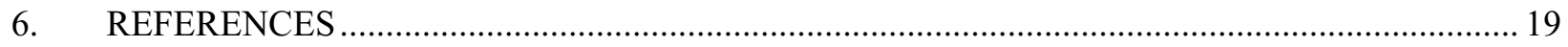

\section{FIGURES}

1. An artist's conception of a direct cycle very high temperature gas cooled reactor and associated hydrogen production plants.

2. Zone $I I I$ in the Ellingham stability diagram is preferred for optimal chromia layer protection against corrosion.

3. Backscattered electron micrograph of a cross-section of Inconel 617 exposed to oxidizing conditions at $1000^{\circ} \mathrm{C}$ for 1000 hours.

4. Schematic of one of the French corrosion test loops. .13

5. Schematic of the INL low velocity controlled chemistry helium materials test system.

6. Details of the retort for exposure of test coupons.

7. Photograph illustrating the seven sapphire seated needle valves used to introduce very precise amounts of impurity and the attached solenoid valves (shown as green in the photo).

8. This plot shows the loop water vapor content being controlled to a set point of 4 ppm for over 50 hours. At approximately 57 hours, the set point was reduced to a value of $2 \mathrm{ppm}$. The duty cycle for the solenoid control valve immediately dropped to less than $0.5 \%$ to bring the water vapor content to $2 \mathrm{ppm}$. 


\section{TABLES}

1. Design characteristics of VHTRs that have been built and operated .................................2

2. Compositions of potential high temperature alloys for NGNP; compositions in

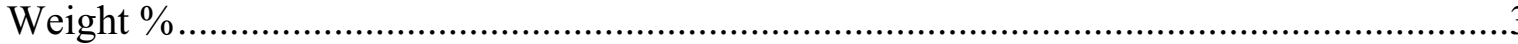

3. Impurities reported in the helium coolant during steady-state operation of VHTRs (in ppm)

4. Primary Coolant Impurities During Rise to Power at Fort St.Vrain (concentrations

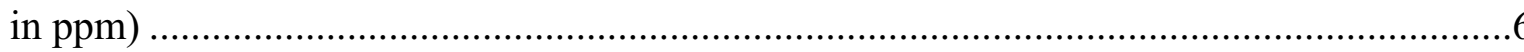

5. Expected levels of impurities in the PBMR ..............................................................

6. Model impurity chemistries used in environmental testing programs (compositions in ppm). HHT, PNP were used for German nuclear process heat projects. AGCNR was a German VHTR, and JAERI B composition was extensively studied in development of the HTTR 


\section{ACRONYMS}

AGCNR Advanced Gas-Cooled Nuclear Reactor

ASTM American Society for Testing and Materials

AVR Arbeitsgemeinschaft Versuchsreaktor (Germany)

HHT High-temperature helium turbine system

HPS Helium Purification System

HTTR High-Temperature Test Reactor (Japan)

INERI International Nuclear Energy Research Initiative

INL Idaho National Laboratory

JAERI Japanese Atomic Energy Research Institute

NGNP Next Generation Nuclear Plant

ORNL Oak Ridge National Laboratory

PBMR Pebble Bed Modular Reactor

PNP Prototype Nuclear Process Heat

ppm parts per million

THTR Thorium High-Temperature Reactor (Germany)

VHTR Very High Temperature Reactor 
This page intentionally left blank. 


\section{Kinetics of Gas Reactions and Environmental Degradation in NGNP Helium}

\section{INTRODUCTION}

The Next Generation Nuclear Plant (NGNP) is being developed to produce hydrogen as well as electricity. Conceptual designs call for a gas-cooled reactor with an outlet temperature greater than the $850^{\circ} \mathrm{C}$ required to efficiently operate the hydrogen generation plant with a maximum of $950^{\circ} \mathrm{C}$. While the design concepts are not yet final, it is highly probable that helium will be the working fluid in the reactor. The primary material in the core will be graphite, and the prime candidates for metallic internal components are the nickel-based alloys Inconel 617 or Alloy 230. An artist's representation of one concept for the reactor and power conversion vessel and the associated hydrogen generation plants is shown in Figure 1. In this representation a heat exchanger in the power conversion vessel (shown in orange in the figure) will take approximately $10 \%$ of the thermal energy of the reactor and divert it as process heat to the hydrogen production plant. Figure 1 shows a direct cycle concept for the reactor. It is also possible that in addition to the process heat being diverted to hydrogen production, there will be a heat exchanger between the primary circuit and a secondary circuit that will drive a gas turbine for electricity production.

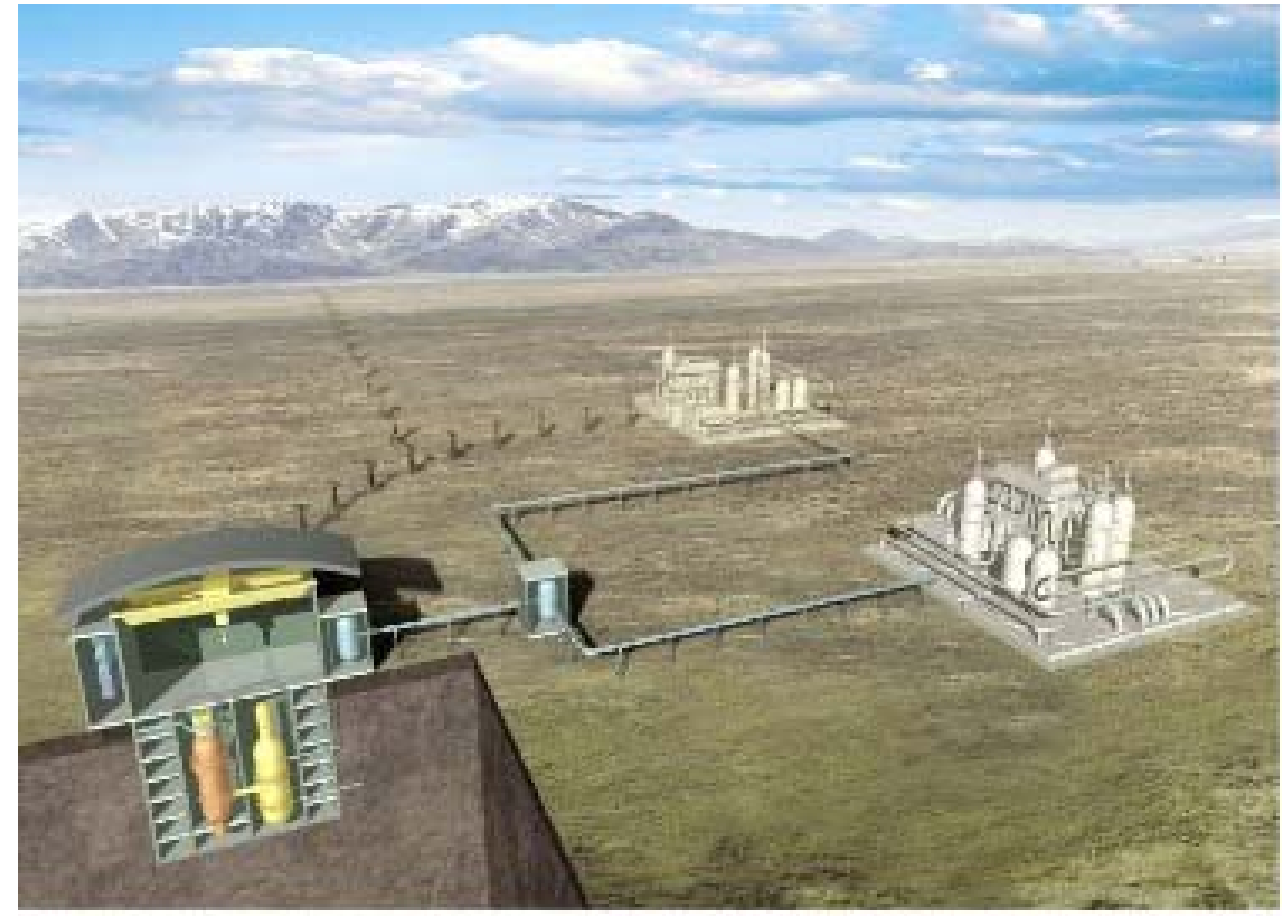

Figure 1. An artist's conception of a direct cycle very high temperature gas cooled reactor and associated hydrogen production plants.

In either case, the most critical metallic component in the NGNP system is the heat exchanger. This heat exchanger will operate at the reactor outlet temperature of up to $950^{\circ} \mathrm{C}$. In addition, the reactor system is intended to have a license period of 60 years. The combination of very high temperature operation and long duration of service restricts material choices for the heat exchanger to a small number of coarse-grained solid-solution strengthened alloys that provide stability and creep resistance and have high chromium content for environmental resistance. 
Very early in the development of nuclear power for electricity generation or for process heat, the concept of an inert gas-cooled, high temperature reactor was explored. The Peach Bottom reactor in the Unites States and the European Dragon project were among the first to seriously address the technical issues associated with high temperature environmental interaction between the cooling gas and metallic components. ${ }^{1-3}$ Proposals for a Very High Temperature Reactor (VHTR) with outlet temperature of $1000^{\circ} \mathrm{C}$ or above were developed by the late 1970's. The Arbeitsgemeinschaft Versuchsreaktor (AVR) was the first experimental pebble bed reactor. A commercial demonstration scale pebble bed, the Thorium High-Temperature Reactor (THTR), was developed based on AVR experience. A summary of important design characteristics for gas-cooled VHTRs that have been operated to date are given in Table $1 .^{1-7}$ The High-Temperature Test Reactor (HTTR) in Japan is the only one of the reactors listed in the table that is still in operation.

Table 1. Design characteristics of VHTRs that have been built and operated. ${ }^{1-7}$

\begin{tabular}{|l|l|l|l|l|l|l|}
\hline & \multicolumn{1}{|c|}{ Dragon } & \multicolumn{1}{c|}{ AVR } & Peach Bottom & Ft. St. Vrain & THTR-300 & HTTR \\
\hline Country of Origin & OECD/Britain & Germany & U.S. & U.S. & Germany & Japan \\
\hline $\begin{array}{l}\text { Thermal Power } \\
\text { MWt }\end{array}$ & 21.5 & 46 & 115 & 842 & 750 & 30 \\
\hline $\begin{array}{l}\text { Net Electric Power } \\
\text { MWe }\end{array}$ & - & 13 & 40 & 330 & 300 & 10 \\
\hline $\begin{array}{l}\text { Maximum Core } \\
\text { Outlet Temp }{ }^{\circ} \mathrm{C}\end{array}$ & 750 & 950 & 725 & 775 & 750 & 950 \\
\hline $\begin{array}{l}\text { Helium Pressure } \\
\text { MPa }\end{array}$ & 2.0 & 1.1 & 2.25 & 4.8 & 3.9 & 4 \\
\hline Steam Temp ${ }^{\circ} \mathrm{C}$ & - & 505 & 538 & 538 & 530 & \\
\hline Reactor Type & Sleeve & Pebble & Sleeve & Block & Pebble & Prism \\
\hline Vessel Material & Steel & Steel & Steel & PCRV & PCRV & Steel \\
\hline $\begin{array}{l}\text { Date of Operation } \\
1964-1975\end{array}$ & 1966 & 1967 & $1979-1989$ & 1985 & 1997 \\
\hline
\end{tabular}

a. Pre-stressed concrete reactor vessel.

The cooling gas of choice for high temperature gas reactors is helium. Although the helium is nominally pure, there are, inevitably, impurities at the parts per million by volume (ppm) levels in the coolant in operating high temperature reactors. Several reviews of the behavior of metallic alloys for control rods, core internals, and heat exchangers in the reactor helium environment are available. ${ }^{8-13}$ The desire for higher temperature operation resulted in evolution of the materials under consideration, from stainless steels to iron-based high temperature alloys to nickel-based alloys. An extensive German program in the 1980's carried out exhaustive studies of the corrosion behavior of the iron-based alloy $800 \mathrm{H}$ for control rods and nickel-based Inconel 617 for structural applications. ${ }^{8-12}$ The Japanese HTTR program extensively studied Haynes Alloy X and developed a variation known as XR with improved properties for some applications, while retaining $800 \mathrm{H}$ for the control rods. ${ }^{14}$ Compositions of these candidate alloys are given in Table $2 .{ }^{14-17}$ Based on creep resistance above $850^{\circ} \mathrm{C}$, the leading candidate alloys for NGNP are Inconel 617 and Haynes 230. 
Table 2. Compositions of potential high temperature alloys for NGNP; compositions in Weight \%.

\begin{tabular}{|c|c|c|c|c|c|c|c|c|c|c|c|}
\hline \multicolumn{1}{|c|}{ Alloy } & $\mathrm{Ni}$ & $\mathrm{Fe}$ & $\mathrm{Cr}$ & $\mathrm{Co}$ & $\mathrm{Mo}$ & $\mathrm{Al}$ & $\mathrm{W}$ & $\mathrm{Ti}$ & $\mathrm{C}$ & $\mathrm{Si}$ & $\mathrm{Mn}$ \\
\hline Inconel 617 & 44.5 & 3 & $20-24$ & $10-15$ & $8-10$ & $0.8-1.5$ & & 0.6 & $0.05-0.15$ & 1 & 1 \\
\hline Alloy 230 & $\mathrm{Bal}$ & 3 & $20-24$ & 5 & $1-3$ & $0.2-0.5$ & $13-15$ & & $0.05-0.15$ & $.25-.75$ & $0.3-1$ \\
\hline Alloy $800 \mathrm{H}$ & $30-35$ & 39.5 & $19-23$ & & & $0.15-0.6$ & & $0.15-0.6$ & $0.05-0.1$ & & \\
\hline Alloy XR & $\mathrm{Bal}$ & 20 & 23 & 1 & 10 & 0.1 & 1 & 0.03 & 0.15 & 0.5 & 1 \\
\hline
\end{tabular}

A common characteristic of the alloys that have been put in service in high temperature gas-cooled reactors is that they rely primarily on the formation of a tenacious chromium scale for long-term protection from environmental interaction with the gas cooling environment. ${ }^{8-10,13}$ The alloys are also primarily solid solution strengthened with carbides on the grain boundaries to stabilize the microstructure and enhance the creep resistance. Sustaining such a protective surface requires sufficient oxygen partial pressure. While helium is normally considered to be inert, experience has shown that the helium in reactors has a number of impurities at low but significant levels that affect the performance of materials depending on the chemistry of the particular alloy, the concentration of impurities, and the temperature the alloy can be oxidized, carburized, or decarburized.

This report will examine what is known about the composition of the helium in reactor environments and the impact of long exposure of metallic alloys to these atmospheres. The influence of the environment of both microstructure and mechanical properties will be discussed. Current programs within the international Generation IV research program will be described and suggestions for additional work will be discussed. ${ }^{18,19}$ 


\section{IMPURITIES IN HELIUM-COOLED HIGH TEMPERATURE GAS-COOLED REACTORS}

All of the high temperature reactor systems operated to date have had extensive gas clean-up systems associated with the helium coolant flow. These systems are intended to keep the total impurity levels in the helium below typically $10 \mathrm{ppm}$. Particularly in the early reactors, where the fuel was either not intended to contain the fission products or was ineffective in this function, the clean up systems were also intended to capture radionuclides. ${ }^{2,3}$ Capture of tritium that is produced (at least in part) by transmutation of lithium impurities in the graphite remains an important function of the clean up system. In the AVR and THTR reactors, active control was maintained on the $\mathrm{H}_{2} \mathrm{O}$ and $\mathrm{CO}$ concentrations to reduce oxidation of the graphite reflectors, and the other impurities were routinely found to reach acceptable steady-state levels without active control. ${ }^{4-7,20,21}$ It has been noted that the clean-up systems may play a secondary role in maintaining gas chemistry, with the massive amount of graphite at high temperature present in all of the reactor designs playing a dominant role. ${ }^{2}$

Molecular sieves are effective in capture of most of the gaseous impurities; however, they have difficulty capturing $\mathrm{H}_{2}$ and $\mathrm{CO}$. To resolve this problem, the gas stream is passed over a bed of $\mathrm{CuO}$ that oxidizes the $\mathrm{H}_{2}$ to $\mathrm{H}_{2} \mathrm{O}$ and $\mathrm{CO}$ to $\mathrm{CO}_{2}$ upstream of the molecular sieve where these gases are effectively removed. The Peach Bottom plant attempted the use of heated Ti getters for hydrogen and tritium; however, these were not effective and oxidation of the $\mathrm{H}_{2}$ prior to removal is now accepted practice. ${ }^{1}$ In a typical plant, up to about $20 \%$ of the gas stream is diverted to the clean up system each hour.

Table 3 shows the impurity levels reported for steady-state operation for several of the VHTRs. ${ }^{1,2,20,21}$ As shown in the table, at steady-state, all of the reactors for which operating data are available had similar levels of impurities. Some caution should be exercised when comparing the data for different plants, since, in some cases, there are varying values reported in different publications for the same plant. This may be associated with conversion from partial pressure of impurities (the preferred units for corrosion studies) to ppm by volume (the typical units used for comparison of one plant to another). Several plants have undergone extensive post-mortem analysis of the core internals and heat exchangers. ${ }^{1,2}$ There are reports of some oxidation and at least one report of massive deposition of carbon on the internals, as discussed in more detail below; however, there have been no problems with failure of components on the primary side associated with environmental effects.

Table 3. Impurities reported in the helium coolant during steady-state operation of VHTRs (in ppm). ${ }^{1,2,20,21}$

\begin{tabular}{|l|c|c|c|c|c|c|c|}
\hline & $\mathrm{H}_{2} \mathrm{O}$ & $\mathrm{H}_{2}$ & $\mathrm{CO}$ & $\mathrm{CO}_{2}$ & $\mathrm{CH}_{4}$ & $\mathrm{O}_{2}$ & $\mathrm{~N}_{2}$ \\
\hline Dragon & 0.1 & 0.1 & 0.05 & 0.02 & 0.1 & 0.1 & 0.05 \\
\hline Peach Bottom & 0.5 & 10 & 0.5 & $<0.05$ & 1.0 & - & 0.5 \\
\hline Fort St. Vrain & 1 & 7 & 3 & 1 & 0.1 & - & - \\
\hline AVR & 0.15 & 9 & 45 & 0.25 & 1 & & 22 \\
\hline THTR & $<0.01$ & 0.8 & 0.4 & 0.2 & 0.1 & & 0.1 \\
\hline
\end{tabular}

High capacity filters are used to remove particulates. It is not entirely clear how significant generation of dust and particulates could be; however, it was shown in the THTR that only $65 \mathrm{~kg}$ of graphite from the reflectors was oxidized and presumably removed as particulate during the total period of plant operation of about two years. ${ }^{4}$ The rate of dust production in AVR was estimated to be $3 \mathrm{~kg}$ per year. ${ }^{22}$ This rate of production corresponds to an average density of dust in the gas of $5 \mu \mathrm{g} / \mathrm{m}^{3}$; the 
corresponding total quantity in the primary circuit is $8 \mathrm{mg}$. Much of the dust was found to settle within the primary circuit in areas of low flow, and a total inventory of $60 \mathrm{~kg}$ was estimated for the primary circuit after over twenty years of operation. Essentially, all of the dust had a particle diameter of less than $2 \mu \mathrm{m}$, and the average particle size was approximately $1 \mu \mathrm{m}$. Note that the AVR was a relatively small experimental reactor that contained approximately 100,000 fuel pebbles, with a total of 30 to 50 spheres transiting the bed per day. Approximately $15 \%$ of the spheres were new, and the rest had previously cycled through the core. The THTR had approximately 675,000 pebbles, and, apparently, the generation rate of dust scales with the size of the core. The most current design for a pebble bed reactor, the Pebble Bed Modular Reactor (PBMR) undergoing final design in South Africa, calls for approximately 450,000 pebbles in the full core.

While dust was not found to pose an operational problem for the AVR system, there is a potential issue with release of radionuclides that are attached to dust particles. ${ }^{22}$ Typical gas-borne dust loads were observed to be near the average; however, they did increase significantly during reactor transients. It is therefore a potential safety issue to remove the dust from the primary system and not allow accumulation.

The pebble bed reactor AVR was used for experiments on the origin of impurity species in the helium coolant, kinetics of reactions between impurities and the reactor system, and gas-gas reactions. ${ }^{20,21}$ It was determined that approximately 10 to $20 \%$ of the $\mathrm{H}_{2}$ in the AVR could be accounted for by adsorption on the 50 new pebbles that were added to the core each day. The remaining $\mathrm{H}_{2}$ was thought to arise from diffusion into the reactor from steam in the secondary circuit. Reaction between iron and water was proposed to be the key step in this process by the reaction:

$3 \mathrm{Fe}+4 \mathrm{H}_{2} \mathrm{O} \leftrightarrow \mathrm{Fe}_{3} \mathrm{O}_{4}+4 \mathrm{H}_{2}$

Hydrogen is strongly adsorbed by the graphite in the reactor core, which tends to limit the amount circulating with the coolant. In experiments using AVR, $\mathrm{H}_{2}$ injected at a level of $6,000 \mu$ bar was reduced to $1000 \mu$ bar in less than 5 hours. The gas purification system could only account for about $10 \%$ of the decrease in concentration. Adsorption is a dynamic process, with some hydrogen being exchanged from the surface to the circulating gas. Increasing the hydrogen concentration therefore causes a release of tritium in the reactor. ${ }^{20,21}$

The AVR used the iron-based Alloy 800 for the heat exchanger, which perhaps facilitated the ingress of hydrogen by the mechanism noted above. Use of nickel-based alloys may suppress hydrogen generation by the reaction above and limit ingress. Detailed experiments have been conducted with chromium oxide forming nickel-based alloys, and it was shown that the formation of $\mathrm{Cr}_{2} \mathrm{O}_{3}$ decreases the hydrogen permeation rate by two to three orders of magnitude. ${ }^{23}$ It is, therefore, not clear how significant the diffusion of hydrogen into the primary circuit (or of tritium into the secondary circuit) will be.

Another major source of impurities has been lubricant from the helium circulators back streaming into the coolant during start-up. The Ft. Saint Vrain plant had very high moisture levels during start-up due to water from the water-lubricated steam-driven helium circulators back streaming into the pressure vessel and impregnating the insulation on the interior of the concrete pressure vessel. ${ }^{1,6}$ Moisture content on the first ascent to power for the Ft. St. Vrain plant is given in Table 4. With each incremental increase in power, there is a corresponding increase in impurities that is shown to decrease with time. The two values shown in the table represent the impurity level at the beginning and end of the hold at any power level. 
Table 4. Primary Coolant Impurities During Rise to Power at Fort St.Vrain (concentrations in ppm).

\begin{tabular}{|l|c|c|c|c|c|c|c|c|}
\hline \multicolumn{1}{|c|}{ Date } & $\begin{array}{c}\text { Power } \\
(\%)\end{array}$ & $\begin{array}{c}\text { Outlet } \\
\text { Temperature } \\
(\mathrm{K})\end{array}$ & $\mathrm{H}_{2}$ & $\mathrm{H}_{2} \mathrm{O}$ & $\mathrm{CO}$ & $\mathrm{CO}_{2}$ & $\mathrm{CH}_{4}$ & $\mathrm{H}_{2} / \mathrm{H}_{2} \mathrm{O}$ \\
\hline July 3-6, 1976 & 2 & 490 & $2-15$ & $240-70$ & 0.2 & $2-1.8$ & 0.6 & $0.01-0.2$ \\
\hline July 24-28, 1976 & 11 & 590 & $45-35$ & $50-25$ & $4-2$ & $6-1$ & $5-3$ & $0.9-1.4$ \\
\hline July 28-30, 1976 & 21 & 700 & $40-90$ & $180-80$ & $2-4$ & $4-10$ & $3-6$ & $0.2-1$ \\
\hline July 30- Aug 2, 1976 & 26 & 785 & $85-30$ & $140-76$ & $4-3$ & $6-10$ & $6-2$ & $0.6-0.4$ \\
\hline Dec 10-Jan 9, 1977 & 28 & 895 & 10 & $40-4$ & $1.5-3$ & $3.5-1$ & $0.5-0.6$ & $0.25-0.25$ \\
\hline Sept 16- Oct 24, 1977 & 38 & 895 & $3-2$ & $<1^{(a)}$ & $4-2$ & $3-2$ & 0.2 & $>3$ \\
\hline Oct 29-31, 1977 & 50 & 945 & 3 & $0.2^{(b)}$ & $6-5$ & $1-1.5$ & $0.4-0.2$ & 15 \\
\hline Apr 28-May 4, 1978 & 65 & 980 & $5-4$ & $<1$ & $10-7$ & $3-2$ & $0.8-0.4$ & $>5$ \\
\hline Dec 10-Jan 27, 1979 & 63 & 945 & $2-7$ & $<1$ & $1-3$ & $0.5-1$ & $0.2-0.1$ & $>3$ \\
\hline
\end{tabular}

(a) Limit of detection of dew point moisture monitors $\sim 1$ ppmv.

(b) $\mathrm{H}_{2} \mathrm{O}$ calculated from $\mathrm{HTO}, \mathrm{HT}$, and $\mathrm{H}_{2}$ measurements: $\mathrm{H}_{2} \mathrm{O}=(\mathrm{HTO})\left(\mathrm{H}_{2}\right)$

After several years of operation, Ft. St. Vrain also had water ingress associated with leakage of a cooling system for the liner of the pre-stressed concrete pressure vessel. ${ }^{6}$ It is perhaps worth noting that while the Ft. St. Vrain plant has a reputation for being an extremely "wet" reactor, the AVR suffered a major water ingress from a leak in the steam generator while the reactor was shut down. Approximately $25 \mathrm{~m}^{3}$ of water entered the pressure vessel before the leak was discovered. ${ }^{24,25}$ Despite this large volume of water, the reactor was refurbished and operated normally again. ${ }^{25}$

The Peach Bottom plant used oil-lubricated helium circulators and had consistently high levels of carbonaceous species in the circulating gas. ${ }^{1,26}$ Upon inspection of the plant internals during decommissioning, it was found that carbon deposits on the order of millimeters in thickness formed in certain parts of the plant. There was no indication of enhanced corrosion associated with these deposits.

The presence of methane in the helium coolant would not be expected on a thermodynamic basis; it should decompose at high temperature into carbon and hydrogen. Experiments using the AVR have shown that a radiolytic process drives the reaction:

$\mathrm{C}+2 \mathrm{H}_{2} \rightarrow \mathrm{CH}_{4}$

This reaction does not appear to result directly from a radiation effect; rather the $\mathrm{H}_{2}$ reacts through interaction with $\mathrm{He}$ that is in an excited state from interaction with neutrons. ${ }^{20}$ There is, therefore, a limit to the amount of $\mathrm{CH}_{4}$ that can be produced when all of the excited He have undergone reaction. This resulted in a constant $\mathrm{H}_{2} / \mathrm{CH}_{4}$ ratio in $\mathrm{AVR}$; at $950^{\circ} \mathrm{C}$ this constant was found to be 100 . It was also found that $\mathrm{N}_{2}$ interacts strongly with excited $\mathrm{He}$ and competes with the methane forming reaction. It was determined in AVR that as the concentration of $\mathrm{N}_{2}$ increased, the $\mathrm{CH}_{4}$ concentration decreased.

Based on operating experience, it has been determined that there is a purification constant associated with the clean-up system for several of the VHTRs. ${ }^{20,21}$ The constant for AVR was $0.04 \mathrm{hr}^{-1}$, while the values for Dragon and Peach Bottom were 0.5 and $0.2 \mathrm{hr}^{-1}$, respectively. Using the purification 
constant for Dragon, one could predict that an initial impurity content of $100 \mathrm{ppm}$ would be reduced to $50 \mathrm{ppm}$ after one hour. It appears that the purification constant is not a function of the particular impurity species. Based on the sources of impurities noted in the discussion above and historical values for purification constants, expected impurity levels for the PBMR have been determined. ${ }^{27}$ The predicted values are shown in Table 5. The range in impurity level is due to the efficiency allocated to the Helium Purification System (HPS), which could range from 20-100\%, depending on the capacity of HPS and the actual impurity levels entering the HPS. The wide range of $\mathrm{N}_{2}$ levels is based on whether or not a cryogenic trap is placed in the system.

Table 5. Expected levels of impurities in the PBMR. ${ }^{27}$

\begin{tabular}{|c|c|c|c|}
\hline \multirow[b]{2}{*}{ Gaseous Element } & \multirow[b]{2}{*}{$\begin{array}{c}\text { Concentration } \\
(\mathrm{ppmv})\end{array}$} & \multicolumn{2}{|c|}{ Impurity Partial Pressure } \\
\hline & & $\begin{array}{c}(\mu \text { bars }) \\
\text { (a) System Pressure of } \\
90 \mathrm{bar}\end{array}$ & $\begin{array}{c}(\mathrm{Pa}) \\
\text { (a) System Pressure of } \\
9 \mathrm{MPa}\end{array}$ \\
\hline $\mathrm{H} 2$ & $2-11$ & $180-1000$ & $18-100$ \\
\hline $\mathrm{H} 2 \mathrm{O}$ & $<0.2$ & $<18$ & $<1.8$ \\
\hline $\mathrm{CO}$ & $2-11$ & $180-1000$ & $18-100$ \\
\hline $\mathrm{CO} 2$ & $<0.2$ & $<18$ & $<1.8$ \\
\hline $\mathrm{CH} 4$ & $<0.1$ & $<10$ & $<1$ \\
\hline $\mathrm{N} 2 *$ & $3-115$ & $270-10000$ & $27-1000$ \\
\hline $\mathrm{He}$ & \multicolumn{3}{|c|}{ Remainder } \\
\hline
\end{tabular}




\section{ENVIRONMENTAL INTERACTIONS BETWEEN VHTR HELIUM AND HIGH TEMPERATURE ALLOYS}

There has been a vast amount of experimental studies and modeling of the effect of VHTR helium on the high temperature alloys listed in Table $1 .^{8,9,11-14,28-38}$ Depending on the specific proposed application, different model chemistries have been developed, and the testing has focused on these. Several of the model impurity chemistries are shown in Table $6 .{ }^{28-38}$ Comparing the values in Table 6 with actual operating experience suggest that the model chemistries tend to have higher impurity levels of some species than those found in operating reactors. This is notable for $\mathrm{H}_{2}$ in particular. It is not clear why these particular values were chosen; however, it can be noted that several of the proposed applications were for process heat for coal gasification, and there was concern that hydrogen would diffuse from the process plant into the primary coolant circuit. ${ }^{28}$ Note that $\mathrm{N}_{2}$, at concentrations similar to those listed in Table 6 has never been found to contribute significantly to environmental interactions with nickel-based alloys. ${ }^{33-34}$

Table 6. Model impurity chemistries used in environmental testing programs (compositions in ppm). HHT, PNP were used for German nuclear process heat projects. AGCNR was a German VHTR, and JAERI B composition was extensively studied in development of the HTTR. ${ }^{28-38}$

\begin{tabular}{|c|c|c|c|c|c|c|c|}
\hline & $\mathrm{H}_{2} \mathrm{O}$ & $\mathrm{H}_{2}$ & $\mathrm{CO}$ & $\mathrm{CO}_{2}$ & $\mathrm{CH}_{4}$ & $\mathrm{O}_{2}$ & $\mathrm{~N}_{2}$ \\
\hline HHT & 0.75 & 250 & 20 & & 25 & & 5 \\
\hline PNP & 0.75 & 250 & 7 & & 10 & & $<2.5$ \\
\hline AGCNR & 1 & 200 & 20 & 0.1 & 10 & & $<2.5$ \\
\hline JAERI B & 0.5 & 100 & 50 & 1 & 2.5 & & $<2.5$ \\
\hline
\end{tabular}

Interplay between the alloy surface, temperature, and gas composition determines whether corrosive oxidation, carburization, or decarburization occurs. The corrosion mechanisms of particular significance to mechanical stability are carburization and decarburization. Carburization is associated with low temperature embrittlement, and decarburization is linked to reduced creep rupture strength. Ideally, a continuous self-healing, impermeable passivating oxide layer is needed to establish the most corrosion-resistant alloy. In the case of Inconel 617, its chromia layer $\left(\mathrm{Cr}_{2} \mathrm{O}_{3}\right)$ is the most important barrier from the effects of corrosive reactor gases.

Of the existing alloys, a nickel chromium alloy Inconel 617 is the leading candidate for use within the NGNP because it has the highest creep strength of the solid solution alloys under consideration for temperatures above $850^{\circ} \mathrm{C}$. Evaluation of this alloy for VHTRs began in the early 1980's with the most comprehensive work done by Quadakkers, Christ and Graham. ${ }^{31-38}$ The newer alloy Haynes 230 is under consideration as an alternative to Inconel 617 because it has equivalent creep properties and may suffer from less internal oxidation.

Based upon the work of Quadakkers and others, assessments of Inconel 617 stability at various gas concentrations and temperatures can be displayed graphically. Quadakkers utilized a modified Ellingham diagram, Figure 2, to display results of the nickel-chromium alloy's stability calculations. ${ }^{31-36,39}$ Five conditions are represented within the diagram: $I$-strongly reducing, $I I$-highly oxidizing, $I I I$-stable external oxide with stable internal carbides, $I V$-strongly carburizing internally and externally, and, lastly, $I V a$ strong external carburization with stable oxide layer. Zone $I I I$ was determined to be the area of highest stability, an environment oxidizing yet slightly carburizing. A heat exchanger operating at temperatures of $900^{\circ} \mathrm{C}$ and assuming AGCNR gas composition Inconel 617 would be in zone III, for example. 


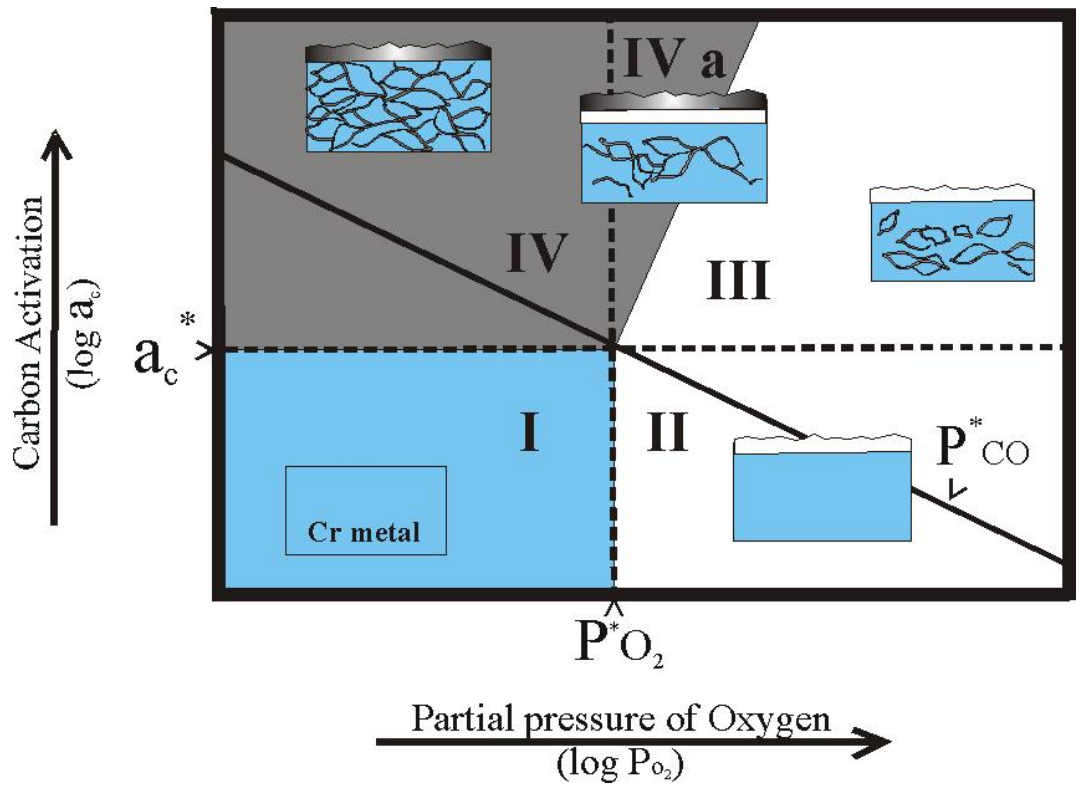

Figure 2. Zone $I I I$ in the Ellingham stability diagram is preferred for optimal chromia layer protection against corrosion.

A backscattered electron micrograph of Inconel 617 exposed to oxidizing conditions is shown in Figure 3. The sample is characterized by an oxide layer that is primarily $\mathrm{Cr}_{2} \mathrm{O}_{3}$ with some Ti present, aluminum-rich internal oxidation along the grain boundaries and a region below the oxidation that is denuded of grain boundary carbides. This zone became depleted of $\mathrm{Cr}_{23} \mathrm{C}_{6}$ grain boundary carbides because of the $\mathrm{Cr}$ segregation to form the oxide layer. A Ni plating was created on the surface of the sample prior to metallographic preparation to help retain the oxide during polishing.

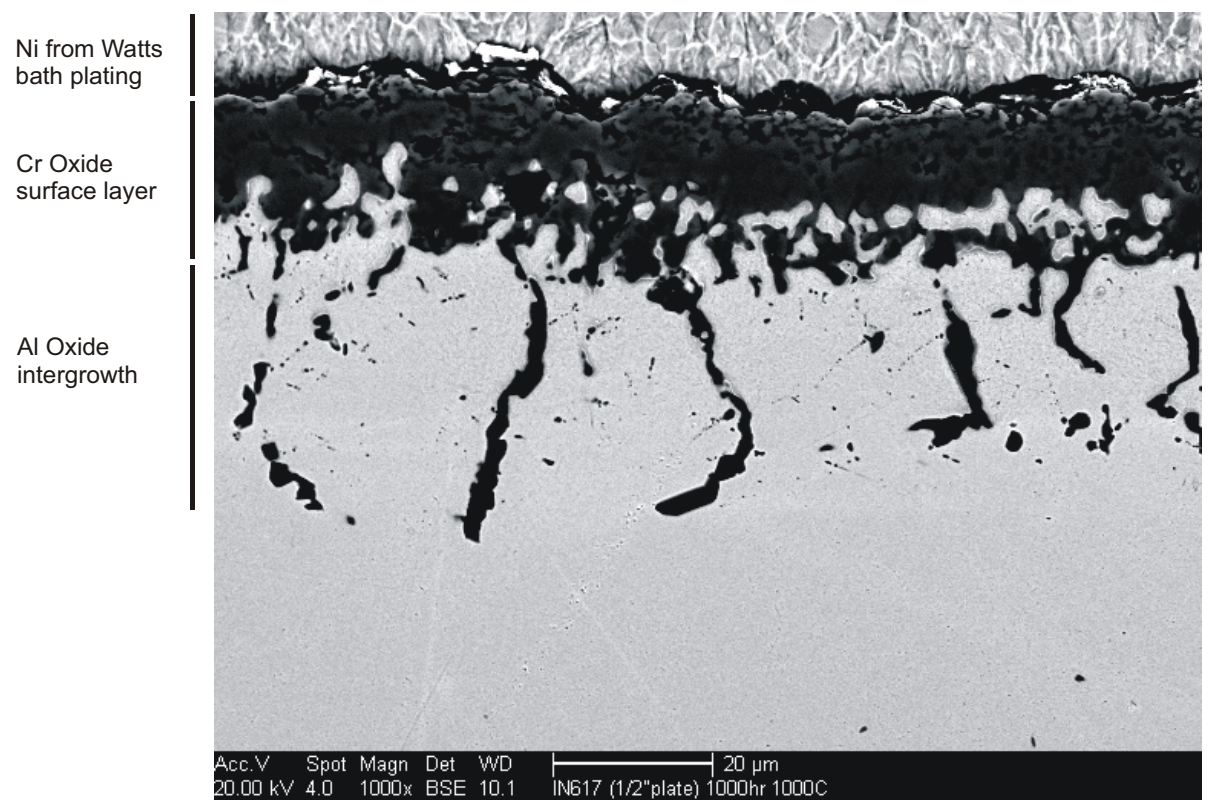

Figure 3. Backscattered electron micrograph of a cross-section of Inconel 617 exposed to oxidizing conditions at $1000^{\circ} \mathrm{C}$ for 1000 hours. 
The modified Ellingham diagram describing alloy stability was based on the most relevant species involved in the corrosion process, namely chromium. Identifying which form $-\mathrm{Cr}_{2} \mathrm{O}_{3}$ chromium carbide, or chromium metal - is most stable in a particular environment will determine the ultimate fate of the alloy. ${ }^{40}$ It is important to note that the gas chemistries found in operating reactors and used in the previous test programs are not in thermodynamic equilibrium. A steady-state gas composition is reached at any temperature based on kinetic considerations. As will be shown below, the concentrations of $\mathrm{H}_{2} \mathrm{O}$ and $\mathrm{CO}$ largely determine the partial pressure of oxygen and activity of carbon, respectively. The important features of the diagram are critical carbon activation $\left(\mathrm{a}_{\mathrm{c}}^{*}\right)$, critical partial pressure of oxygen $\left(\mathrm{P}^{*} \mathrm{O}_{2}\right)$, and the critical partial pressure of carbon monoxide $\left(\mathrm{P}^{*} \mathrm{CO}\right)$. These parameters are calculated from the following thermodynamic reactions:

$$
\begin{array}{lll}
\mathrm{a}_{\mathrm{c}}^{*} & 23 \mathrm{Cr}+6 \mathrm{C}=\mathrm{Cr}_{23} \mathrm{C}_{6} & \text { metal-carbide equilibrium activity } \\
\mathrm{P}^{*} & \mathrm{O}_{2} \mathrm{Cr}_{2} \mathrm{O}_{3}=2 \mathrm{Cr}+1.5 \mathrm{O}_{2} & \text { disassociation pressure of chromia } \\
\mathrm{P} * & \mathrm{CO} 3 \mathrm{CO}+2 \mathrm{Cr}=\mathrm{Cr}_{2} \mathrm{O}_{3}+3 \mathrm{C} & \mathrm{CO} \text { pressure for this equilibrium }
\end{array}
$$

The measured steady-state conditions (AGCNR gas composition) determine where the alloy sits within the Ellingham diagram; hence, the steady-state carbon activity $\left(\mathrm{a}_{\mathrm{c}}{ }^{\mathrm{ss}}\right)$ and the steady-state oxygen pressure $\left(\mathrm{PO}_{2}^{\mathrm{ss}}\right)$ are calculated with the following equations:

$$
\begin{array}{lll}
\mathrm{a}_{\mathrm{c}}^{\mathrm{ss}} & \mathrm{CO}=\mathrm{C}+0.5 \mathrm{O}_{2} & \mathrm{a}_{\mathrm{c}}^{\mathrm{ss}}=\mathrm{K} \cdot\left(\mathrm{P}_{\mathrm{CO}}{ }^{\mathrm{ss}} / \mathrm{P}_{\mathrm{O} 2}{ }^{\mathrm{ss} 1 / 2}\right) \\
\mathrm{PO}_{2}{ }^{\mathrm{ss}} & \mathrm{H}_{2} \mathrm{O}=\mathrm{H}_{2}+[\mathrm{O}] & \mathrm{PO}_{2}{ }^{\mathrm{ss}}=\left(\mathrm{K}^{\cdot} \cdot \mathrm{PH}_{2} \mathrm{O} / \mathrm{PH}_{2}\right)^{2} \cdot\left(1-\left(\mathrm{PCH}_{4} / \mathrm{PH}_{2} \mathrm{O}\right) \cdot 1 / 100\right)
\end{array}
$$

In order to properly calculate important parameters in the diagram, the chemical activity of chromium is needed. A brief description is necessary before continuing. The chemical activity is defined by the relationship:

$a=f \cdot \mathrm{c}$

where

$$
\begin{array}{ll}
a & =\text { chemical activity } \\
f & =\text { activity coefficient } \\
\text { c } & =\text { concentration }
\end{array}
$$

Two approaches are cited for finding chromium activities which employ two different methods: electrolyte cell approach ${ }^{41}$ and the Knudsen mass spectroscopy cell approach. ${ }^{42}$ In an electrolyte cell the chromium activity is determined from the relationship:

$a_{C r}=e^{(-3 E F / R T)}$

where

$$
\begin{array}{ll}
\mathrm{a}_{\mathrm{Cr}} & =\text { chromium activity } \\
\mathrm{E} & =\text { open circuit potential (volts) } \\
\mathrm{F} & =\text { Faraday's constant }(23,066 \mathrm{cal} / \text { volt) }
\end{array}
$$


$\mathrm{R}=$ Universal gas constant $(1.987 \mathrm{cal} / \mathrm{g})$

$\mathrm{T} \quad=$ is in Kelvin.

From Knudsen Cell mass spectroscopy the activity can be determined by the relationships:

$\mathrm{a}_{\mathrm{Cr}}=\mathrm{P}_{\mathrm{Cr}}($ alloy $) / \mathrm{P}_{\mathrm{Cr}}($ pure $)$

where

$$
\begin{aligned}
& \mathrm{a}_{\mathrm{Cr}} \quad=\text { chromium activity } \\
& \mathrm{P} \quad=\text { partial pressure }
\end{aligned}
$$

$\Delta \mathrm{G}_{\mathrm{i}}=\mathrm{RT} \ln \mathrm{a}_{\mathrm{i}}$

$\Delta \mathrm{G}_{\mathrm{i}}^{\mathrm{xs}}=\Delta \mathrm{G}_{\mathrm{i}}-\mathrm{RT} \ln \mathrm{N}_{\mathrm{i}}$

where

$$
\begin{aligned}
& \Delta \mathrm{G}_{\mathrm{i}} \quad=\text { partial free energies of mixing } \\
& \Delta \mathrm{G}_{\mathrm{i}}^{\mathrm{xs}}=\text { excess partial free energies } \\
& \mathrm{N}_{\mathrm{i}} \quad=\text { molar fractions of component } \mathrm{i} \\
& \mathrm{a}^{*}{ }_{\mathrm{Cr}}=10^{((620 / \mathrm{T})-0.981)} \text { formula of chromium activity for Inconel } 617 \\
& \mathrm{~T} \quad=\text { is in Kelvin. }
\end{aligned}
$$

Data from the mass spectroscopy approach was chosen for the calculations of stability in the NGNP program because of its specific measurement for the Inconel 617 alloy. ${ }^{42}$ Unfortunately, a range of chromium activities has been reported for bulk alloys, which is problematic, since the main features of the diagram have chromium activities as a variable. ${ }^{43}$ Pinning down an exact value can be difficult, especially because of a high temperature phenomenon referred to as a 'microclimate,' or critical temperature event associated with irreversible destruction of chromium oxides and carbides. 33,34

A local chromium activity of 0.75 is associated with the following reaction: ${ }^{33-34}$

$$
2 \mathrm{Cr}_{2} \mathrm{O}_{3}+\mathrm{Cr}_{23} \mathrm{C}_{6}=6 \mathrm{CO}+27 \mathrm{Cr} \text {. }
$$

The onset of this event occurs at a particular temperature, $\mathrm{T}_{\mathrm{A}}$, when the $\mathrm{CO}$ concentration is no longer sufficient to drive the reaction from right to left. It results in eventual total loss of either chromium oxide or carbide, depending on concentration, then complete carburization or decarburization of the alloy, depending on the gas composition. This degradation mechanism is not considered in the stability diagrams developed using the approach of Quadakkers; however, it has been discussed extensively by Graham and Christ. ${ }^{33,34,36-38}$ Important variables are temperature $\mathrm{T}_{\mathrm{A}}\left(\sim 980^{\circ} \mathrm{C}\right.$ for Inconel 617 with the AGCNR chemsitry) and measured CO pressure verses $\mathrm{P}^{*} \mathrm{CO}$. At the temperature $\mathrm{T}_{\mathrm{A}}$, the reaction will go to completion, and, as a result, this temperature represents a maximum use temperature for the particular alloy for a given gas composition. 
Another shortcoming of the stability diagram approach presented above is that it does not account for the fact that $\mathrm{Cr}_{2} \mathrm{O}_{3}$ becomes volatile at a temperature above about $950^{\circ} \mathrm{C}^{44}$

There may be sufficient oxygen partial pressure to form the oxide as predicted from the modified Ellingham diagram; however, it will not be protective because of the very high vapor pressure of the oxide. Most laboratory studies have been at very low flow rates to more closely approach thermodynamic equilibrium for fundamental studies of corrosion mechanisms. It has been noted that these conditions may not be representative of reactor systems, where very high gas velocities are likely, e.g., 50 to $75 \mathrm{~ms}^{-1}$ at the outlet of the NGNP. ${ }^{33-34}$ With very low levels of impurities, this increases the possibility that impurities will be depleted during the experiments and may give rise to anomalously low values for $\mathrm{Cr}_{2} \mathrm{O}_{3}$ vaporization in test systems compared to reactor operation. ${ }^{30}$

Another issue that has not been comprehensively studied is the potential influence of impurities in the helium at reactor pressure. As noted above, typical test protocols have employed a pressure of $2 \mathrm{~atm}$, while the NGNP will operate at a pressure of approximately $60 \mathrm{~atm}$. It is thought that the mechanism of environmental interaction will remain unchanged for equivalent values of partial pressure of impurities; however, the kinetics may be significantly increased. A relatively large (10 MW thermal) test loop was built as part of the THTR development program and operated at up to $40 \mathrm{~atm}$ helium pressure (with PNP composition) and moderately high flow rates. ${ }^{45}$ The test conditions varied between 700 and $950^{\circ} \mathrm{C}$; after 7,000 hours at $950^{\circ} \mathrm{C}$ under these conditions, Inconel 617 had only surface oxidation. These results suggest that higher velocity and high pressure do not substantially change the corrosion behavior. Another quasi-static test apparatus examined corrosion behavior of Hastelloy X, Alloy 800, and Inconel 617 in helium with $50 \mu \mathrm{atm}$ of water, $450 \mu \mathrm{atm}$ of $\mathrm{CO}$ at total pressures of 2 and $50 \mathrm{~atm}$, and temperatures up to $870^{\circ} \mathrm{C}^{46}$ Although the experiments suggested that the kinetics of corrosion were increased at high pressure while the mechanism remained the same, the authors were doubtful that their chemistry measurement and control were sufficiently accurate to draw firm conclusions. 


\section{CURRENT TESTING PROGRAMS FOR VHTR ENVIRONMENTAL INTERACTIONS}

There is currently a project in the NGNP materials program to investigate environmental effects on the microstructure of Inconel 617 and Haynes 230 in plate form as well as fusion welds in both materials. This project is being carried out jointly between Idaho National Laboratory (INL) and Oak Ridge National Laboratory (ORNL). The behavior of common lots of material is being characterized in helium with impurities at the AGCNR model chemistry values shown in Table 6 . The main focus of the investigation is determining the influence of changes in the $\mathrm{H}_{2} \mathrm{O}$ and $\mathrm{CO}$ concentrations on the mechanism of corrosion at temperatures up to $1000^{\circ} \mathrm{C}$. A computer program has been developed aimed at predicting whether the interaction between the alloy and a particular chemistry for a given temperature is oxidizing, carburizing, or decarburizing based on Quadakker's approach. ${ }^{31,32}$ The approach being taken in this program is to predict behavior for chemistries within different regions in the stability diagram and then carry out well-controlled experiments to characterize the actual behavior. Despite the extensive programs examining environmental interactions under similar conditions in the past, there is sufficient uncertainty in some of the parameters that go into the model, particularly the chromium activity, thermochemistry of chromium carbides, and the influence of minor alloying elements, to create uncertainty about the boundaries between different degradation mechanisms.

There is a parallel effort within the Generation IV program, particularly in France. An International Nuclear Energy Research Initiative (INERI) has been established between the U.S. program and the French program as a formal mechanism to exchange information. The focus and approach of the two programs is somewhat different so that they are largely complementary rather than duplicative. A schematic of one of the test systems used in the French corrosion program is shown in Figure 4 below. This system uses a single test coupon and makes dynamic measurements of weight gain or loss. Gas flow in the system is once through and uses premixed gas compositions. In contrast to the loops being operated in the U.S., the French systems tend to use due point measurements for the concentration of $\mathrm{H}_{2} \mathrm{O}$. While these systems are somewhat more complex than the solid-state devices used in the U.S., they are capable of measuring water concentrations at values much less than one ppm. The French program has been carrying out experimental work for several years and preliminary results have been published. ${ }^{47-49}$

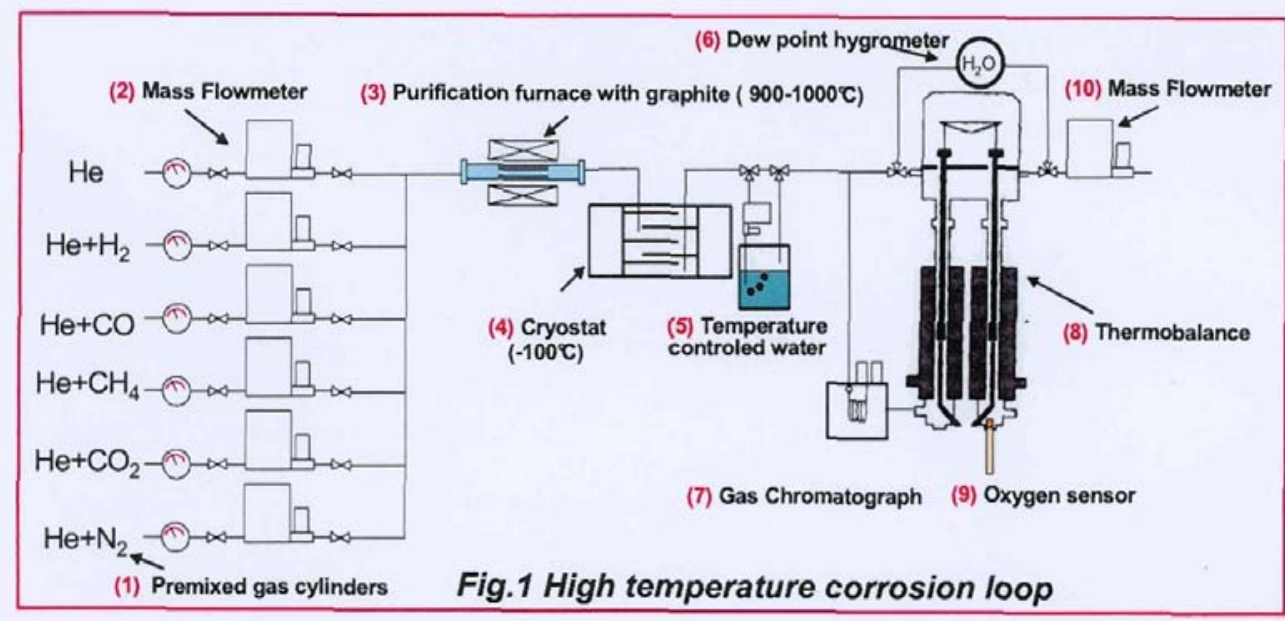

Figure 4. Schematic of one of the French corrosion test loops. 
The NGNP experimental environmental effects project has concentrated on establishing test loops at INL and ORNL. A closed-circuit, low flow velocity test loop has been designed and assembled at INL. This loop has the ability to expose coupons and mechanical test specimens in a controlled impurity atmosphere at high temperature for long periods. The test system at ORNL has been designed such that the gas chemistry is controlled by bleeding off a portion of the test atmosphere and refreshing to the desired chemistry with controlled additions of gas. While the INL system is designed so that it can operate in this mode, it is also designed with the potential to continuously getter excess impurities and add necessary trace impurities based on mass spectroscopy measurements in a closed loop system.

A schematic of the components of the test loop is shown in Figure 5. The schematic shows that the system has a vent system that will only be used in the so-called "bleed and feed" mode of operation. The system can be evacuated to a pressure of $10^{-6}$ torr in the specimen chamber using a turbo-molecular pump. All of the tubing for the system is stainless steel and can be heated during evacuation to help remove adsorbed impurities. There is a metal bellows pump in the loop capable of $40 \mathrm{l} / \mathrm{m}$ flow; the total system volume is approximately 20 liters.

The test section consists of concentric quartz tubes inside the furnace section where cool gas moves down through the annulus and returns up past specimens that will be suspended on a central rod. The hot zone of the retort is approximately $0.75 \mathrm{~m}$ in length and is designed to operate up to $1000^{\circ} \mathrm{C}$. The quartz tubes are sealed to the system using an o-ring assembly that allows tubes to be disassembled to insert and retrieve specimens and to replace quartz tubes as necessary. Details of the retort and fittings are shown in Figure 6. Although provision has been made to water cool the aluminum fittings that hold the o-ring seal assembly for the quartz tubes, experiments with flowing helium up to $1000^{\circ} \mathrm{C}$ have indicated that it will probably not be necessary.

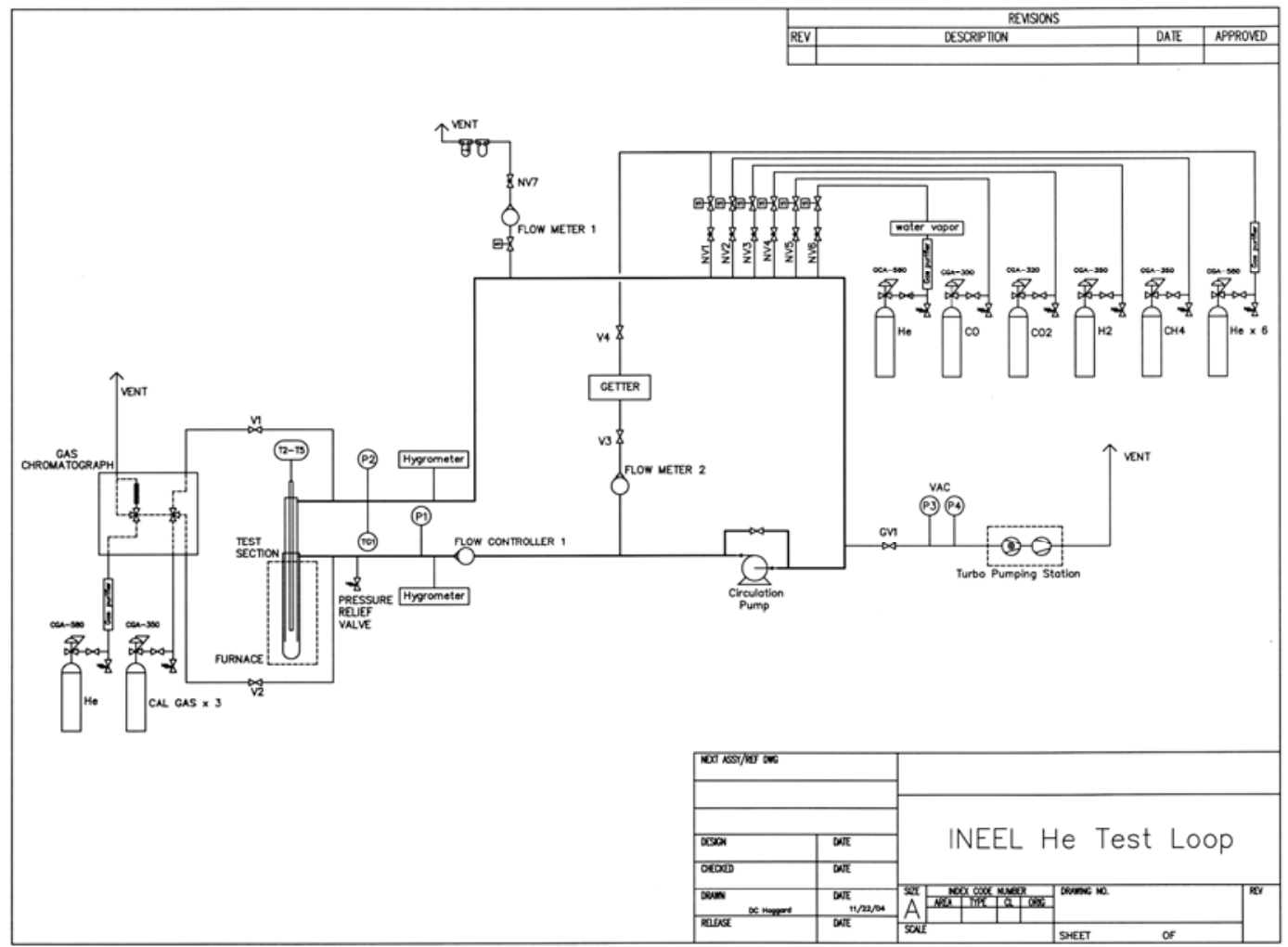

Figure 5. Schematic of the INL low velocity controlled chemistry helium materials test system. 


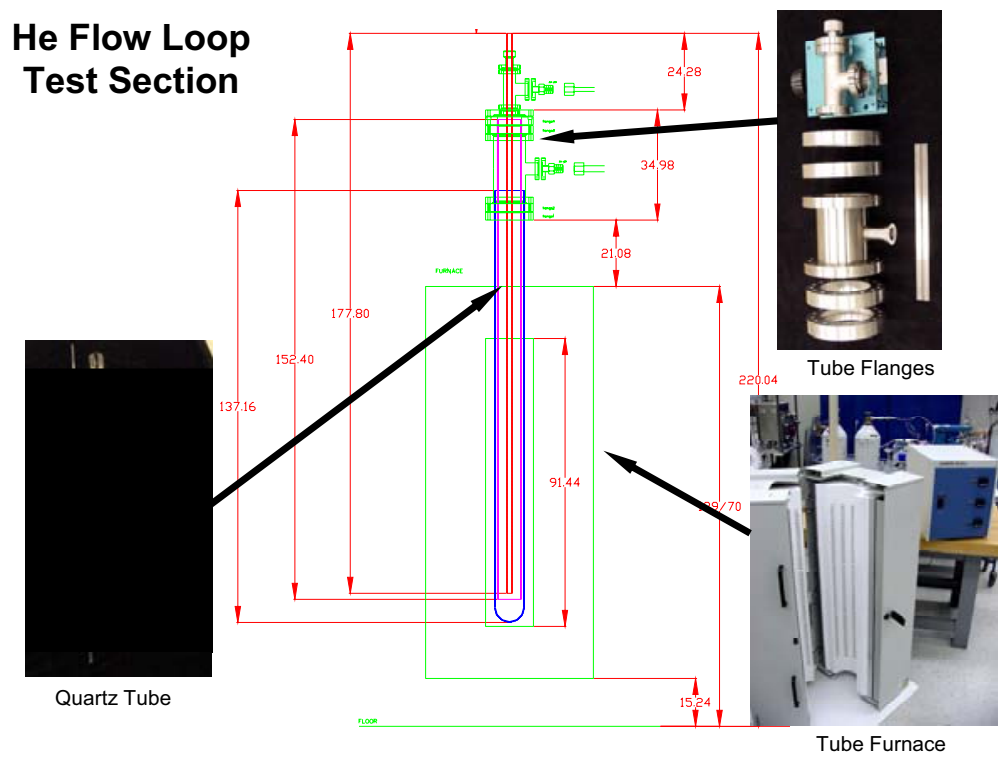

Figure 6. Details of the retort for exposure of test coupons.

Gas composition is measured going into the retort and upon exit from the hot zone. Water vapor content is measured using solid-state hygrometers. The content of the other impurities is measured using a gas chromatograph with a pulsed ionization source. All of the gas compositions will be measured to one part per million or less. As shown in Figure 5, all of the impurities are added to the system as individual gases, rather than premixing gases. A sapphire seated needle valve is used to very precisely control the introduction of each impurity gas into the system. To automate impurity additions, solenoid operated valves are used to control the gas that is introduced to the needle valve. A photograph of the needle valves with the attached solenoid operated valves is shown in Figure 7.

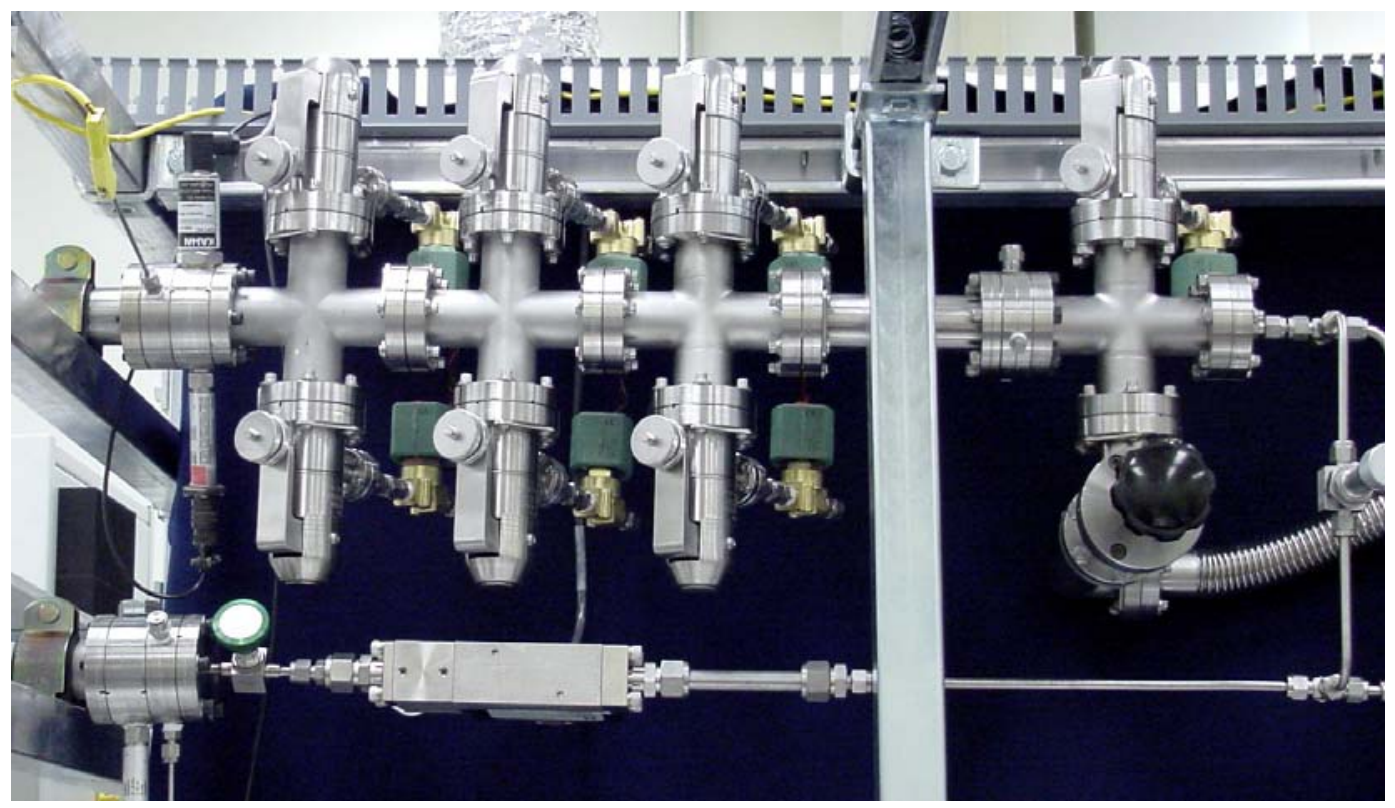

Figure 7. Photograph illustrating the seven sapphire seated needle valves used to introduce very precise amounts of impurity and the attached solenoid valves (shown as green in the photo). 
The high temperature corrosion loops currently in use for both the U.S. and French programs use gas chromatography with pulsed ionization sources to determine the impurity levels in the helium. This method has the advantage of using commercially available systems that are relatively inexpensive, require minimal calibration, and clearly distinguish between each of the impurity species. The disadvantage of this method is that the measurement time for each gas sample is typically between 10 and 20 minutes, and the lower level of detection for most of the impurities of interest is about $1 \mathrm{ppm}$. Christ et al., developed a corrosion test system using quadrupole mass spectroscopy capable of determining impurity concentrations to levels of less than $0.1 \mathrm{ppm}$ in real time.$^{50}$ The system was used extensively to determine the dynamics of gas interactions with surfaces. While the system had fast response time, it had to operate at very low pressure (less than $10^{-8} \mathrm{~Pa}$ ), and, due to fragmentation of gas molecules during ionization, there were many overlapping mass peaks e.g., $\mathrm{CO}_{2}, \mathrm{~N}_{2}$ and $\mathrm{CO}$. This resulted in the need for complex methods of calibration and deconvolution of the peaks.

Much of the current effort using the INL corrosion loop has focused on control of the gas chemistry and characterization of the ability to maintain precise control of impurity levels for sustained periods up to 1000 hours (the anticipated length of corrosion tests). Control of water is particularly difficult. As noted above, the French test loops only measure water levels, they do not attempt active control. The graph below shows control of the water content at the $4 \mathrm{ppm}$ level for a sustained period followed by controlled change in the level to $2 \mathrm{ppm}$. The duty cycle of the solenoid valve is shown on the plot; this is the fraction of the time that the valve is active in controlling flow of moist helium into the loop. For a set point of $2 \mathrm{ppm}$ of water, the valve is cycling at a very low fraction of its potential; thus, this is near the lower limit of active control for this system.

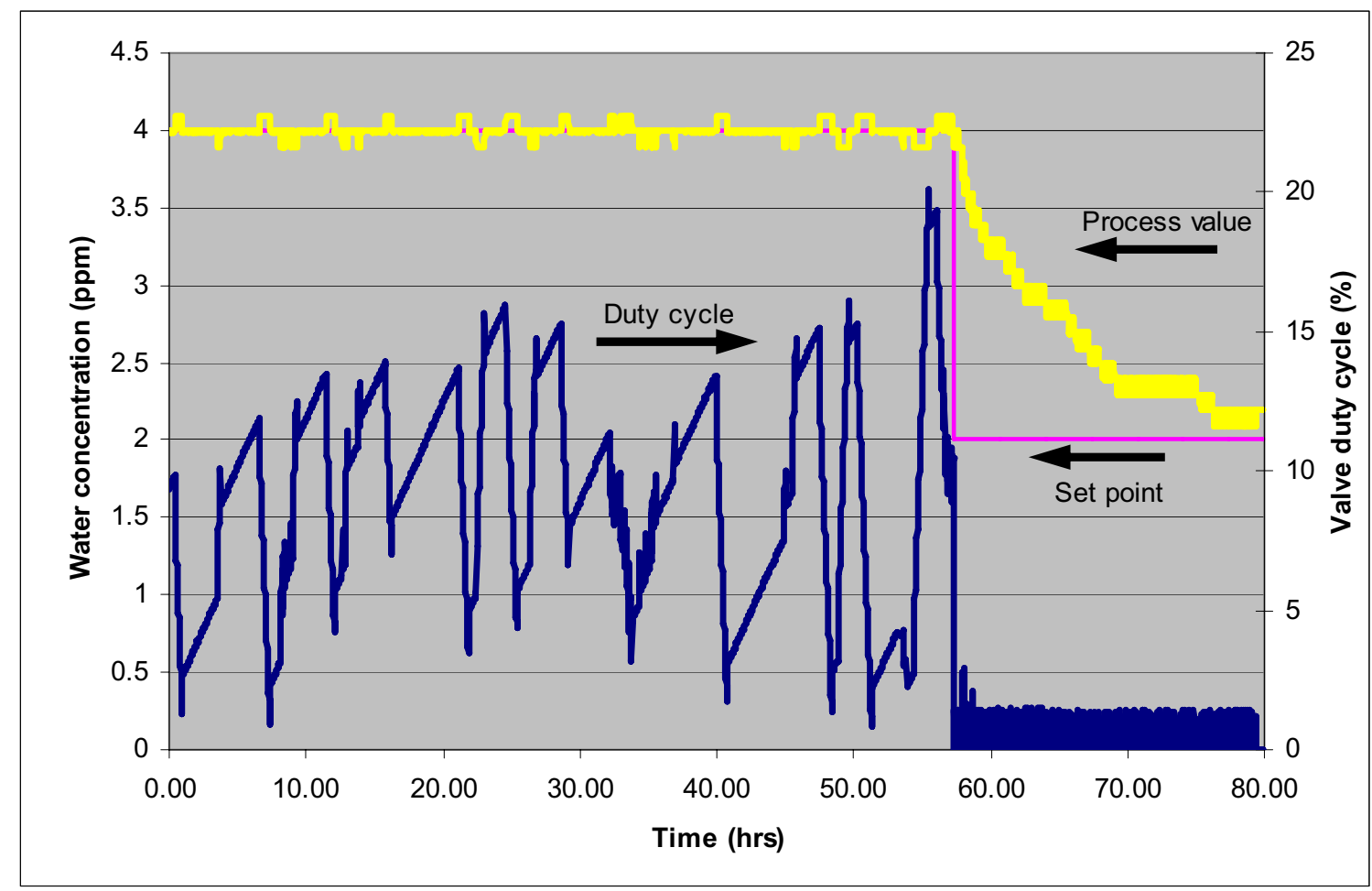

Figure 8. This plot shows the loop water vapor content being controlled to a set point of $4 \mathrm{ppm}$ for over 50 hours. At approximately 57 hours, the set point was reduced to a value of $2 \mathrm{ppm}$. The duty cycle for the solenoid control valve immediately dropped to less than $0.5 \%$ to bring the water vapor content to 2 ppm. 
As noted previously, because of the low flow rates in coupon test loops, the current U.S. and French programs intend to determine mechanisms of corrosion but will contribute little to understanding the kinetics of environmental effects under reactor conditions. Since there is no coolant chemistry that is inert with respect to Inconel 617 or Haynes 230, the overall approach of the two programs is to determine a range of impurity levels, focused primarily on $\mathrm{H}_{2} \mathrm{O}$ and $\mathrm{CO}$, where the environmental interaction is slightly oxidizing at the temperatures of interest. The U.S. program intends to focus primarily on experimental confirmation of the modified Ellingham diagrams that describe corrosion mechanisms at higher temperatures than previous studies and on coupons containing fusion welds. The French program will carry out similar characterizations; however, that program has a particular focus on establishing the upper limit on service temperature determined by the microclimate reaction. ${ }^{49}$

Both the U.S. and French programs are investigating Inconel 617 alloys with restrictions on particular alloy elements to optimize some property, but which remain within the ASTM specification. The French program has obtained a heat of Inconel 617 with minimum levels of Al and Ti with the anticipation that this modification will reduce the amount of internal oxidation along grain boundaries as shown in Figure 3. The U.S. program has determined that optimum creep properties at the highest temperatures require the maximum allowable levels of $\mathrm{Al}$ and $\mathrm{Ti}$ and a heat of Inconel 617 with this type of chemistry has been obtained. It should be noted that Haynes 230 has been selected for parallel studies because it appears to have comparable creep properties compared to Inconel 617 and perhaps displays less internal oxidation. 


\section{CONCLUSIONS}

Environmental degradation in VHTR helium has been extensively studied. Depending on the temperature and levels of impurities, nickel-based alloys can be oxidized, decarburized, or carburized by long-term exposure. In addition, there is a maximum service temperature for each alloy determined by the microclimate reaction or volatilization of $\mathrm{Cr}_{2} \mathrm{O}_{3}$. The impurity levels in the coolant for VHTRs that have operated fall within a narrow range, which, perhaps fortuitously, are in the stable oxidizing condition for chromia forming alloys. There have been no reports of significant corrosion on the primary side of operating VHTRs.

There are two significant issues that remain to be investigated with respect to possible environmental interactions in the NGNP: environmental interaction at reactor pressure and the influence of very high velocity gas on the environmental interaction. While, it is anticipated that the reaction mechanism determined using low pressure test loops will also be observed at high pressure, there is some concern that the kinetics of reaction will be altered. Although, as noted above, particulate erosion is not expected to be of concern, it is possible that the steady-state gas chemistry at the specimen surface could be considerably different with high velocity flow. 


\section{REFERENCES}

1. R. D. Burnette and N. L. Baldwin, 1980, "Primary Coolant Chemistry of the Peach Bottom and Fort St. Vrain High Temperature Gas-Cooled Reactors," Specialists Meeting on Coolant Chemistry, Plate-out and Decontamination in Gas Cooled Reactors, Juelich, Germany, December 1980, IAEA, Vienna, IWGGCR-2, pp. 132-137.

2. R. A. Simon and P. D. Capp, 2002, "Operating Experience with the Dragon High Temperature Reactor Experiment," Proceedings on High Temperature Reactors, Petten, Netherlands, April 2002, IAEA, Vienna, HTR-2002. pp. 1-6.

3. E. N. Shaw, 1983, History of the Dragon Project - Europe's Nuclear Power Experiment, Pergamon Press.

4. R. Baumer and I. Kalwowski, 1991, “THTR Commissioning and Operating Experience,” Energy, Vol. 16, pp. 59-70.

5. H. L. Brey, 1991, "Fort St. Vrain Operations and Future,” Energy, Vol. 16 pp. 47-58,.

6. C. H. Fuller, 1989, "Fort Saint Vrain Operational Experience.” Design Requirements, Operation and Maintenance of Gas-Cooled Reactors, San Diego, CA, International Atomic Energy Agency.

7. B. Bäumer, H. Barnet, et al., eds. 1990, AVR - Experimental High-Temperature Reactor; 21 Years of Successful Operation for a Future Energy Technology, Düsseldorf, Germany, Association of German Engineers (VDI), The Society for Energy Technologies.

8. H. Nickel, T. Kondo, et al., 1984, "Status of Metallic Materials Development for Application in Advanced High-Temperature Gas-Cooled Reactors," Nuclear Technology, Vol. 66, pp. 12-22.

9. Nickel, F. Schubert, et al., 1984, "Evaluation of Alloys for Advanced High-Temperature Reactor Systems," Nuclear Engineering and Design, Vol. 78, pp. 251-265.

10. Bodmann, H. Diehl, et al., 1988, "Service Conditions and Relevant Properties of HTGR Metallic Materials," High Temperature Metallic Materials for Gas-cooled Reactors., Krakow, Poland, International Atomic Energy Agency, Vienna, Austria, pp. 15-27.

11. H. Nickel, F. Schubert, et al., 1990, "Development and Qualification of Materials for Structural Components for the High-Temperature Gas-Cooled Reactor," Nuclear Engineering and Design, Vol. 121, pp. 183-192..

12. H. Nickel, E. Bodmann, et al., 1991, "The Materials Program for the HTR in the FRG: Integrity Concept, Status of the Development of High Temperature Materials and Design Codes," Energy, Vol. 16(1/2), pp. 221-242.

13. K. Natesan, A. Purohit, et al., 2003, Materials Behavior in HTGR Environments, ANL-02/37, February, 2003.

14. R. Tanaka and T. Kondo, 1984, "Research and Development on Heat-Resistant Alloys for Nuclear Process Heating in Japan," Materials Technology, Vol. 66, pp. 76-87.

15. Special Metals Product Bulletin Inconel Alloy 617, Huntington, WV, 2005. 
16. Special Metals Product Bulletin Alloy 230, Huntington, WV, 2005.

17. Special Metals Product Bulletin Alloy 800H, Huntington, WV, 2005.

18. P. Billot and D. Barbier, 2004, "Very High Temperature Reactor (VHTR) the French Atomic Energy Commission (Cea) R\&D Program," Proceedings of the Conference on High Temperature Reactors HTR-2004, Beijing, China, (2004) International Atomic Energy Agency, Vienna, Austria.

19. D. E. Buckthorpe, 2004, "Results from EU 5th Framework HTR Projects HTR-M \& HTR-M1." Proceedings of the Conference on High Temperature Reactors HTR-2004, Beijing, China, (2004) International Atomic Energy Agency, Vienna, Austria.

20. R. Nieder and W. Stroter, 1988, "Long-term Behavior of Impurities in an HTR Primary Circuit," VGB Kraftwerstechnik, Vol. 68, July 1988, pp. 671-676.

21. R. Nieder, 1980, "Prediction on an HTR Coolant Composition After Operational Experience with Experimental Reactors," Specialists Meeting on Coolant Chemistry, Plate-out and Decontamination in Gas Cooled Reactors, Juelich, FRG, December 1980, IAEA, Vienna, IWGGCR-2, pp. 144-152.

22. C.B. von der Decken and U. Wawrzik, 1990, "Dust and Activity Behavior," AVR - Experimental High-Temperature Reactor 21 Years of Successful Operation for a Future Energy Technology, The Society for energy Technologies, VDI Verlag, Dusseldorf, pp. 265-266.

23. J. Schaefer, D. Stover, and R. Hecker, 1984, "Terms and Results of Hydrogen Permeation Testing of Oxide-Scaled High-Temperature Alloys," Nuclear Technology, Vol. 66, pp. 537-548.

24. D. Stolzl, 1990, "Twenty-five Years of Brown Boveri Experience in Development, Design and Fabrication of Circulators for HTGR," AVR - Experimental High-Temperature Reactor 21 Years of Successful Operation for a Future Energy Technology, The Society for energy Technologies, VDI Verlag, Dusseldorf, pp. 53-59.

25. R. Nieder and K. Vey, 1980, "Chemical Reactions During Nuclear Drying of the AVR Primary Circuit Following a Water Ingress," Specialists Meeting on Coolant Chemistry, Plate-out and Decontamination in Gas Cooled Reactors, Juelich, FRG, December 1980, IAEA, Vienna, IWGGCR-2, pp. 137-144.

26. W.T. Scheffel, N. L. Baldwin, and R. W. Tomlin, 1976, Operating History Report for the Peach Bottom HTGR Volume 1 - Reactor Operating History, GA-A13907 Volume 1 UC 77, p. 13-6.

27. Kobus Smit, PBMR, personal communication.

28. H. G. A. Bates, 1984, "The Corrosion Behavior of High-Temperature Alloys During Exposure for Times up to $10,000 \mathrm{H}$ in Prototype Nuclear Process Helium at 700 to $900^{\circ} \mathrm{C}$," Nuclear Technology 66: $415-428$.

29. J. Fujioka, N. Fukasaka, et al, 1984, "Mechanical Properties of Heat-Resistant Alloys Exposed to Air and HTGR Helium at High Temperatures," Nuclear Technology 66: 175-184.

30. H. Inouye, 1984. "Relationship of $\mathrm{H}_{2} \mathrm{O}$ and $\mathrm{CH}_{4}$ Supply Rates in HTGR Helium to the Carburization of Hastelloy-X and Alloy 800h," Nuclear Technology 66: 392-403. 
31. W. J. Quadakkers and H. Schuster, 1985, "Corrosion of High Temperature Alloys in the Primary Circuit Helium of High Temperature Gas Cooled Reactors. - Part I: Theoretical Background," Werkstoffe und Korrosion, Vol. 36, pp.141-150.

32. W. J. Quadakkers, 1985, "Corrosion of High Temperature Alloys in the Primary Circuit Helium of High Temperature Gas Cooled Reactors. Part II: Experimental Results,"Werkstoffe und Korrosion, Vol. 36, pp. 335-347.

33. H. J. Christ, D. Schwanke, Th. Uihlein, and H. G. Sockel, 1988, "Mechanisms of HighTemperature Corrosion in Helium Containing Small Amounts of Impurities. I. Theoretical and Experimental Characterization of the Gas Phase," Oxidation of Metals, Vol. 30, pp. 1-26.

34. H. J. Christ, U. Kunecke, K. Meyer, and H. G. Sockel, 1988, "Mechanisms of High-Temperature Corrosion in Helium Containing Small Amounts of Impurities. II. Corrosion of Nickel- Base Alloy Inconel 617," Oxidation of Metals, Vol. 30, pp. 27-51.

35. W. J. Quadakkers and H. Schuster, 1988, "Corrosion Behaviour of High Temperature Alloys in the Cooling Gas of High Temperature Reactors," High Temperature Metallic Materials for GasCooled Reactors, Cracow, Poland, International Atomic Energy Agency, Vienna, Austria.

36. H. J. Christ, U. Kunecke, K. Meyer, and H. G. Sockel, 1987, "High Temperature Cossosion of the Nickel-Based Alloy Inconel 617 in Helium containing Small Amounts of Impurities," Materials Science and Engineering, Vol. 87, pp. 161-168.

37. L. W. Graham, 1977, "Corrosion of Metallic Materials in HTR-Helium Environments," Journal of Nuclear Materials, Vol. 171, pp. 155-178.

38. K. G. E. Brenner, and L. W. Graham, 1984, "The Development and Application of a Unified Corrosion Model for High-Temperature Gas-Cooled Reactor Systems," Nuclear Technology, Vol. 66, pp. 404-414.

39. C. S. Giggins and F. S. Pettit, 1980, "Corrosion of Metals and Alloys in Mixed Gas Environments at Elevated Temperatures," Oxidation of Metals, Vol. 14, pp. 363-413.

40. A. Roine, Outokumpu HSC Chemistry for Windows, version 5.1, Outokumpu Research Oy.

41. F. N. Mazandarany and R. D. Pehlke, 1973, "Thermodynamic Properties of Solid Alloys of Chromium with Nickel and Iron,” Metallurgical Transactions, Vol. 4, pp. 2067-2076.

42. K. Hilpert, H. Gerads, and D. H. Lupton, 1979, "Mass Spectrometric Studies of Alloys Proposed for High Temperature Reactor Systems II. Inconel alloy 617 and nimonic alloy PE 13," Journal of Nuclear Materials, Vol. 80, pp. 126-131.

43. R. O. Williams, 1982, "Thermodynamics of the Superalloys," Metallurgical Transactions A, Vol. 13A, pp. 959-965.

44. H. J. Grabke and G. Horz, 1977, "Kinetics and Mechanisms of Gas-Metal Reactions," Annual Review of Materials Science, Vol. 7, pp. 155-178.

45. R. Harth, W. Jansing, and H. Teubner, 1990, "Experience Gained from the EVA II and KVK Operation," Nuclear Engineering and Design, Vol. 121, pp. 173-182. 
46. M. Cappelaere, M. Perrot, and J. Sannier, 1984, "Behavior of Metallic Materials Between 550 and $870^{\circ} \mathrm{C}$ in High-Temperature Gas-Cooled Reactor Helium Under Pressures of 2 and 50 Bar," Nuclear Technology, Vol. 66, pp. 465-478.

47. C. Cabet, A. Terlain, P. Lett, L. Guetaz, and J. M. Gentzbittel, 2006, "High Temperature Corrosion of Structural Materials Under Gas-Cooled Reactor Helium," to be published in Materials and Corrosion, Vol. 57.

48. C. Cabet, A. Mpnnier, and A. Terlain, 2004, "Corrosion of High Temperature Alloys in the Coolant Helium of a Gas Cooled Reactor," Materials Science Forum, Vols. 461-464, pp. 11651172 .

49. D. Kaczorowski and P. Combrade, May 2005, "Corrosion in Impure VHTR Helium: The Framatome Corrosion Loop," to be published in Proceedings $13^{\text {th }}$ International Conference on Nuclear Engineering, Beijing, ICONE 13-50634.

50. H. J. Christ, D. Schwanke, T. Uihlein, and H. G. Sockel, 1986, "Quantative mass spectrometer analysis of very low impurity concentrations in gases," Journal of Physics E, Vol. 19, pp. 793-798. 